\title{
Type D Lymphomatoid Papulosis
}

National Cancer Institute

\section{Source}

National Cancer Institute. Type D Lymphomatoid Papulosis. NCI Thesaurus. Code C139014.

A variant of lymphomatoid papulosis which mimics primary cutaneous aggressive epidermotropic CD8-positive cytotoxic T-cell lymphoma. 